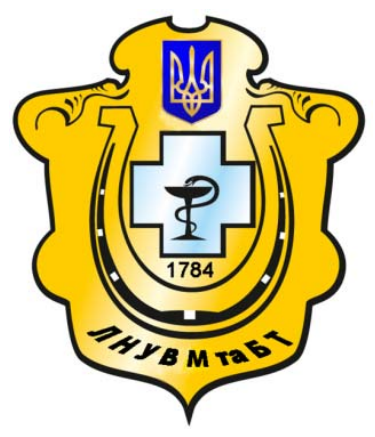

Науковий вісник Львівського національного університету ветеринарної медицини та біотехнологій імені С.3. Гжицького

Scientific Messenger of Lviv National University of Veterinary Medicine and Biotechnologies named after S.Z. Gzhytskyj

doi:10.15421/nvlvet7709

ISSN 2518-7554 print

ISSN 2518-1327 online

$\underline{\text { http://nvlvet.com.ua/ }}$

УДК 591.471.35./.473.3:598.252.3

\title{
Біоморфологічні особливості м'язів, які діють на тазостегновий суглоб, у деяких представників родини лебеді - GENUS CYGNUS
}

\author{
Н.В. Друзь \\ druz_nv3011@ukr.net \\ Національний університет біоресурсів і природокористування Украӥни, \\ вул. Героїв Оборони, 15, м. Київ, 03041, Україна
}

\begin{abstract}
У статті викладено узагальнені результати оригінального системного морфо-функиіонального та морфо-екологічного дослідження м'язів апарату біпедальної локомоції класу птахів, а саме ряду гусеподібних, родини лебеді. Вперше наводиться детальна розробка порівняльної анатомії тазових кінцівок птахів, щяо супроводжується унікальним історичним оглядом та охоплює більш ніж двохтисячолітній період. Проведено аналіз деяких значущих морфологічних структур, щяо дає ключі до реконструкиії адаптивної еволюиії будь-якої групи птахів. Також викладено біоморфологічні особливості м'язів тазостегнового суглоба представників родини лебеді. Встановлено, щзо у представників даного ряду ступінь диференціації м'язів тазостегнового суглоба обумовлений крокуючим типом біпедальної локомоиії, а також біоморфологічними особливостями статики, що у свою чергу накладає певні відбитки на ступінь розвитку кожного окремого м'яза тазостегнового суглоба.

Що являє собою біоморфологія як окремий напрямок морфологї̈? Це - синтез екології та морфологї̈ різних таксономічних груп птахів, оскільки кожен вид має свою екологічну нішу, за межами якої існувати не може. Нинішніх вчених цікавить питання, щуо стосується міжвидових особливостей статики і локомоції різних видів птахів. Кожен окремий вид птахів - унікальний своїми анатомічними компонентами, які виникли на основі пристосування їх до життя в різних середовищах і функціональних навантаженнях з боку маси тіла, щзо і підтверджують наші дослідження. Птахи добре пристосувалися до різних умов існування: до життя в болотах, водного способу життя в повітрі, лісах $і$ чагарниках, на рівнинах або скелях. Сучасна біоморфологія вивчає не тільки морфологічні особливості будови тіла, в даному випадку птахів, а й середовище проживання, яке б могло вплинути на відмінності тих чи інших органів. Наприклад, багато птахів, використовують повітря як середовище пересування і як середовище видобутку їжі, більшу частину доби проводять у польоті. Вони мають найдосконаліший літальний апарат. Деякі птахи використовують як середовище існування $і$ видобутку їжі, вони мають відповідні пристосування, які розвивалися в двох напрямках: пристосування крил і пристосування ніг.

Ключові слова: біоморфологія, тазова кінцівка, тазостегновий суглоб, птахи, рід лебеді, лебідь-иипун, чорний лебідь
\end{abstract}

\section{Биорфологические особенности мышц, которые действуют на тазобедренный сустав, у некоторых представителей семейства лебеди - GENUS CYGNUS}

\author{
Н.В. Друзь \\ druz_nv3011@ukr.net
}

Национальныцй университет биоресурсов и природопользования Украины, ул. Героев Обороны, 15, Киев, 03041, Украина

В статье изложены обобщенные результаты оригинального системного морфо-функиионального и морфоэкологического исследования мыши аппарата бипедальной локомочии класса птии, а именно отряда гусеобразных, рода лебеди. Впервые приводится детальная разработка сравнительной анатомии тазовых конечностей птии, сопровождает-

Citation:

Druz, N.V. (2017). Biomorphological features of muscles that act on hip joint in some representatives of GENUS CYGNUS. Scientific Messenger LNUVMBT named after S.Z. Gzhytskyj, 19(77), 38-40. 
ся уникальным историческим обзором и охватывает более двухтысячелетний период. Проведенный анализ некоторых значимых морфологических структур, дает ключ к реконструкции адаптивной эволючии любой группь птиц. Также изложены биоморфологические особенности мыиц тазобедренного сустава представителей рода лебеди. Установлено, что у представителей данного ряда степень дифференциации мыши тазобедренного сустава обусловлен шагаюшим типом бипедальнои локомоции, а также биоморфологическими особенностями статики, что в свою очередь накладывает определенные отпечатки на степень развития каждой отдельной мышицы тазобедренного сустава.

Что представляет собой биоморфология как отдельное направление морфологии? Это - синтез экологии и морфологии различных таксономических групп птиц, поскольку каждый вид имеет свою экологическую нишу, за пределами которой существовать не может. Ньнешних ученых интересует вопрос, касаюшийся межвидовых особенностей статики и локомоции различных видов птиц. Каждый отдельный вид птии - уникальный свочми анатомическими компонентами, которые возникли на основе приспособления к жизни в разных средах и функциональных нагрузках со стороны массы тела, что и подтверждают наши исследования. Птиць хорошо приспособились к различным условиям существования: к жизни в болотах, водному образу жизни в воздухе, лесах и кустарниках, на равнинах или скалах.

Современная биоморфология изучает не только морфологические особенности строения тела, в данном случае птии, но и среду обитания, которая могла повлиять на различия тех или иных органов. Например, много птиц, используют воздух в качестве среды передвижения и как среду добычи пищи, большую часть суток проводят в полете. Они имеют самыи летательный аппарат. Некоторые птицы используют как среду обитания и добычи пищи воду, они также имеют соответствуюшие приспособления котрые развивались в двух направлениях: приспособление крыльев и приспособление ног.

Ключевье слова: биоморфология, тазовая конечность, тазобедренный сустав, птиць, род лебеди, лебедь-иипун, черный лебедь.

\title{
Biomorphological features of muscles that act on hip joint in some representatives of GENUS CYGNUS
}

\author{
N.V. Druz \\ druz_nv3011@ukr.net \\ National University of Life and Environmental Sciences of Ukraine, \\ Heroyiv Oborony Str., 15, Kyiv, 03041, Ukraine
}

The article presents the summarized results of the original system morpho-functional and morpho-ecological research of muscles of the bipedaly locomotion apparatus of birds, in particular of number Anseriformes, type swans. For the first time it is provides a detailed design of comparative anatomy of birds pelvic limbs, accompanied by unique historical overview and covers more than twothousand-year period. It was hold the analysis of some significant morphological structures, that gives a key to the reconstruction of the adaptive evolution of any group of birds. Also it is described biomorphological features of hip joint's muscles of the genus swans. It was found that representatives of the given number have a degree of differentiation of hip joint's muscles, caused by walking type of bipedaly locomotion and biomorphological features of static, which in turn imposes certain imprints on the degree of development of each muscle of the hip joint.

What is biomorphology as a separate line of morphology? This is the synthesis of ecology and morphology of different taxonomic groups of birds, since each type has its own ecological niche, outside which it can not exist. Nowdays scientist are interested in the current issues, concering inter-specific features of static and locomotion of various species of birds. Each single species of birds is unique by its anatomical components, arising from their adaptation to life in different environments and functional load of the body weight, what is confirmed by our study. Birds are well adapted to the different conditions of existence: to live in swamps, aquatic life in air, in forests and thickets, on plains and rocks. Modern biomorphology studies not only morphological features of the body structure, in this case of birds, but the habitat that could affect on the differences of the various organs. For example, many birds use air as a travel medium and as a medium of food production, and spend most of the day in flight. They have the most developed aircraft. Some birds use water as habitat and food production, and also have suitable adaptations, that have evolved in two directions: adaptation of wings and adaptation of legs.

Key words: biomorphology, pelvic limb, hip joint, birds, genus swan, mute swan, black swan.

\section{Вступ}

Незважаючи на значні досягнення як вітчизняних, так і зарубіжних дослідників в області морфології хребетних тварин, багато питань, пов'язаних з розробкою видової і породної анатомії птахів, донині залишаються невивченими. Особливо це стосується м'язової системи птахів i, зокрема, ділянки тазостегнового суглоба (Druz' and Mel'nik, 2016). Тому великий науковий інтерес становить вивчення іiі топографії та щільного взаємозв'язку між формою, структурою і функціями м'язово-скелетної системи (Melnyk et al., 2012; Melnyk and Druz, 2015).

\section{Матеріал і методи досліджень}

Дослідження проводилися на базі кафедри анатомії та гістології тварин ім. акад. В. Г. Касьяненка НУБіП України (м. Київ, Україна) на фіксованих 10\% розчином формаліну трупах представників роду лебеді.

\section{Результати та їх обговорення}

Каудальний клубово-вертлужний м'яз у чорного лебедя і у лебедя-шипуна починається товстим, потужним, широким, але коротким сухожилком на латеральній поверхні великого вертлюга стегнової кістки. Присутній м'язовий апоневроз і сухожильна перетин- 
ка. Закінчується м'яз на латеральній поверхні іiї краніального кінця. М'яз двоперистий.

Краніальний клубово-вертлужний м'яз бере початок на латеральній поверхні великого вертлюга стегнової кістки, в її дистальній третини. Виявлена сухожильна перетинка. У чорного лебедя м'яз повздовжньоволокнистий, а у лебедя-шипуна - двоперистий.

Зовнішній клубово-вертлужний м'яз, за точкам фіксації, починається довгим, міцним сухожилком на дорсо-латеральній поверхні великого вертлюга стегнової кістки. Закінчується м'язово на дорсальному гребні клубової кістки, на каудальному іiі краї. М'яз повздовжньоволокнистий.

Внутрішній клубово-стегновий м'яз починається м'язово 3 дистальної частини клубової кістки і закінчується на краніо-медіальній поверхні проксимальної третини стегнової кістки. М'яз повздовжньоволокнистий.

У обох представників ряду гусеподібних глибокий сідничо-стегновий м'яз - повздовжньоволокнистий і починається широким, потужним, порівняно довгим сухожилком на каудальній поверхні стегнової кістки. Точка фіксації даного м'яза спільна 3 хвостовостегновим м'язом. М'яз закінчується м'язово на дорсо-дистальному краї сідничної кістки. У чорного лебедя на медіальній поверхні м'яз відводить дві сухожильні ніжки, які проходять через сідничний отвір прямо до хребта. У лебедя-шипуна він диференційований на два пласти: поверхневий і глибокий, але чіткої межі не видно. М'яз повздовжньоволокнистий.

Хвостово-стегновий м'яз, бере початок потужним, широким, порівняно довгим сухожилком на каудальній поверхні середньої третини стегнової кістки, точка фіксації спільна з глибоким сіднично-стегновим м'язом. Сухожилок переходить в м'язові волокна, що ближче до хвостового відділу переходять в широке, потужне сухожилля, яке проходить під пігостиль, у чорного лебедя, охоплюючи його, як сумкою, при цьому об'єднуючись $з$ однойменним м'язом протилежного боку. У лебедя-шипуна місце фіксації диференційоване на дві ніжки: сухожильна і м'язова ніжка. М'яз повздовжньоволокнистий.

Сідничо-стегновий м'яз починається на каудолатеральній поверхні стегнової кістки нижче від великого вертлюга потужним, широким, але коротким сухожиллям. У чорного лебедя м'яз на медіальній поверхні відводить сухожильну ніжку, яка заходить вглиб через сідничний отвір. Точка кінцевої фіксації м'язу в обох видів збігається - на латеральній поверхні сідничної кістки. У чорного лебедя м'яз двоперистий, а у лебедя-шипуна - одноперистий.

Медіальний затульний м'яз у чорного лебедя диференціюється на три ніжки: проксимальна (м'язова), дистальна (м'язова) і середня (сухожильна). М'яз на каудальній частині має слабо диференційоване від основної маси м'яза м'язове черевце. Всі ніжки кріпляться на каудальній поверхні проксимального кінця стегнової кістки. Ніжки проходять через затульний отвір та щільно прилягають до сідничної і лобкової кісток. М'яз двоперистий і має сухожильну перетинку.

Медіальний затульний м'яз у лебедя-шипуна починається потужним сухожиллям на каудолатеральній поверхні проксимального кінця стегнової кістки. М'яз переходить на медіальну поверхню через затульний отвір, де м'язовими волокнами щільно прилягає до сухожильної мембрани, яка розташована між лобковою і сідничою кістками. М'яз двоперистий.

Вентральний сідничо-стегновий м'яз починається м'язово на каудальній поверхні стегнової кістки. Закінчується на вентральному краї затульного отвору. М'яз повздовжньоволокнистий. Затульно-стегновий м'яз виявлений тільки у лебедя-шипуна. Починається м'язово-сухожильно на каудальній поверхні стегнової кістки і закінчується м'язовими волокнами в ділянціі проксимального краю затульного отвору. М'яз повздовжньоволокнистий.

\section{Висновки}

1. Доведено, що м'язи тазостегнового суглоба у різних видів птахів відрізняються за ступенем розвитку, диференціацією, наявністю або відсутністю різних типів перистості. Це обумовлено тільки типом опори, способом пересування і функціональними навантаженнями під час стато-локомоції.

2. Відсутність або наявність в досліджених видів птахів тих чи інших м'язів, їх головок, частин i м'язових пластів можна пояснити тільки дією функціональних навантажень з боку маси тіла.

\section{Бібліографічні посилання}

Druz', N.V., Mel'nik, O.P. (2016). Stato-lokomocija tazovyh konechnostej ptic s biomorfologicheskoj tochki zrenija. Minskij gosudarstvennyj medicinskij universitet «Dostizhenija i innovacii v sovremennoj morfologii». Minsk. 2, 142-145 (in Russian).

Melnyk, O.P., Druz, N.V. (2015). Biomorfolohichnyi analiz lokomotornoho aparatu tazovoi kintsivky ptakhiv. zbirnyk tez NUBiP Ukrainy. 56-57 (in Ukrainian).

Melnyk O.P., Druz N.V., Nikitov, V.P. (2012). Stan i perspektyvy vyvchennia biomorfolohii miaziv dilianky stehna ptakhiv. Naukovyi visnyk NUBiP Ukrainy. K. VTs NUBiP Ukrainy. 172(1), 273 (in Ukrainian).

Стаття надійшла до редакції 28.02.2017 